\title{
Histone Deacetylases as New Therapeutic Targets in Triple-negative Breast Cancer: Progress and Promises
}

\author{
NIKOLAOS GARMPIS ${ }^{1 *}$, CHRISTOS DAMASKOS $^{1,2^{*}}$, ANNA GARMPI $^{3 *}$, EMMANOUIL KALAMPOKAS $^{4}$, \\ THEODOROS KALAMPOKAS ${ }^{5}$, ELEFTHERIOS SPARTALIS ${ }^{2}$, AFRODITE DASKALOPOULOU $^{2}$, \\ SERENA VALSAMI ${ }^{6}$, MICHAEL KONTOS $^{7}$, AFRODITI NONNI ${ }^{8}$, KONSTANTINOS KONTZOGLOU ${ }^{1}$, \\ DESPINA PERREA ${ }^{2}$, NIKOLAOS NIKITEAS ${ }^{2}$ and DIMITRIOS DIMITROULIS ${ }^{1}$ \\ ${ }^{1}$ Second Department of Propedeutic Surgery, Laiko General Hospital, \\ National and Kapodistrian University of Athens, Medical School, Athens, Greece; \\ ${ }^{2}$ N.S. Christeas Laboratory of Experimental Surgery and Surgical Research, Medical School, \\ National and Kapodistrian University of Athens, Athens, Greece; \\ ${ }^{3}$ Internal Medicine Department, Laiko General Hospital, University of Athens Medical School, Athens, Greece; \\ ${ }^{4}$ Gynaecological Oncology Department, University of Aberdeen, Aberdeen, U.K.; \\ ${ }^{5}$ Assisted Conception Unit, Second Department of Obstetrics and Gynecology, Aretaieion Hospital, Medical School, \\ National and Kapodistrian University of Athens, Athens, Greece; \\ ${ }^{6}$ Blood Transfusion Department, Aretaieion Hospital, Medical School, \\ National and Kapodistrian Athens University, Athens, Greece; \\ ${ }^{7}$ First Department of Surgery, Laiko General Hospital, Medical School, \\ National and Kapodistrian University of Athens, Athens, Greece; \\ ${ }^{8}$ First Department of Pathology, School of Medicine, \\ National and Kapodistrian University of Athens, Athens, Greece
}

\begin{abstract}
Triple-negative breast cancer (TNBC) lacks expression of estrogen receptor (ER), progesterone receptor (PR) and HER2 gene. It comprises approximately 15-20\% of breast cancers (BCS). Unfortunately, TNBC's treatment continues to be a clinical problem because of its relatively poor prognosis, its aggressiveness and the lack of targeted therapies, leaving chemotherapy as the mainstay of treatment. It is essential to find new therapies against TNBC, in order to surpass the resistance and the invasiveness of already existing
\end{abstract}

This article is freely accessible online.

\footnotetext{
*These Authors contributed equally to this study.

Correspondence to: Nikolaos Garmpis, MD, Second Department of Propedeutic Surgery, Laiko General Hospital, National and Kapodistrian University of Athens, Medical School, 17 Agiou Thoma Street, 11527, Athens, Greece. Tel: +30 6976291403, Fax: +30 2132061772, e-mail: nikosg22@hotmail.com
}

Key Words: Histone deacetylase, HDAC inhibitors, breast cancer, triple negative, epigenetics, review. therapies. Given the fact that epigenetic processes control both the initiation and progression of TNBC, there is an increasing interest in the mechanisms, molecules and signaling pathways that participate at the epigenetic modulation of genes expressed in carcinogenesis. The acetylation of histone proteins provokes the transcription of genes involved in cell growth, and the expression of histone deacetylases (HDACs) is frequently up-regulated in many malignancies. Unfortunately, in the field of BC, HDAC inhibitors have shown limited effect as single agents. Nevertheless, their use in combination with kinase inhibitors, autophagy inhibitors, ionizing radiation, or two HDAC inhibitors together is currently being evaluated. HDAC inhibitors such as suberoylanilidehydroxamic acid (SAHA), sodium butyrate, mocetinostat, panobinostat, entinostat, YCWI and $\mathrm{N}-(2-$ hydroxyphenyl)-2-propylpentanamide have shown promising therapeutic outcomes against TNBC, especially when they are used in combination with other anticancer agents. More studies concerning HDAC inhibitors in breast carcinomas along with a more accurate understanding of the TNBC's pathobiology are required for the possible identification of new therapeutic strategies. 
According to the World Health Organization, breast cancer (BC) is the most frequently diagnosed cancer and the second leading cause of cancer-related death, among women worldwide. Interestingly, according to the American Cancer Society about $12 \%$ of women in U.S.A. will develop BC during their lifetime (1-4). There is a variety of risk factors that are associated with $\mathrm{BC}$ such as gender, age, ethnicity or lifestyle, but it is now clear that the most dangerous factor for the development of BC is heredity. In particular, in high-risk families, there have been reported more than 1.000 mutations of breast cancer 1 (BRCAl) and breast cancer 2 (BRCA2) genes (1).

$\mathrm{BC}$ is a very heterogeneous disease given that its invasive process is associated with a variety of molecular alterations. These changes lead to different subtypes of the disease. The current classification divides BC subtypes into Luminal A, Luminal B, HER2-positive and $\operatorname{TNBC}(5,6)$. A better explanation of $\mathrm{BC}$ classification and the corresponding cell lines are presented in Table I $(7,8)$.

First of all, Luminal A and B represent from $65 \%$ to $80 \%$ of total $\mathrm{BC}$ disease. More specifically they account $50-60 \%$ and $15-20 \%$ respectively (9). These subtypes are generally correlated to a good prognosis. They are known to express the estrogen receptor (ER-positive) that participates in cell proliferation, viability, and invasion of BC cells. We should mention that patients with luminal B tumors frequently present a worse prognosis than Luminal A patients. This could be explained as in Luminal B tumors HER2 gene, which is associated with potent proliferation, can be amplified (10). The substantial difference though, between Luminal A and B patients is the cell proliferation rate which is higher in the latter.

Secondly, there is the subtype of HER2-positive patients who amplify the oncogene $H E R 2$. These tumors are ER negative, so they are different from Luminal B cancers. Unfortunately, hormonotherapy is inefficient against HER2positive tumors. During the last 20 years the development of novel drugs targeting HER2 (e.g. trastuzumab, lapatinib, pertuzumab) has enhanced the clinical outcomes (1).

Moreover, another severe subtype of $\mathrm{BC}$ is triple negative breast cancer (TNBC). It is associated with poor prognosis. TNBC does not express either estrogen, or progesterone receptors, or HER2 gene. These tumors can be further classified in several subtypes. The first subgroup is basal-like, where tumors express some characteristics of breast myoepithelial cells. Basal-like tumors are highly proliferative and are associated with very poor prognosis. Another subgroup is claudin-low, which presents epithelial to mesenchymal transition (EMT) and stem cell-like or/and tumor initiating cell features (11). This subtype is also associated with poor prognosis.

Neoadjuvant anthracycline/taxane-based chemotherapies (e.g., docetaxel, doxorubicin, cyclophosphamide) have been tested in TNBC patients with poor prognosis (5).
Table I. Classification of breast cancers and their relation to breast cancer cell lines.

\begin{tabular}{lcc}
\hline Classification & Immuno-profile & Cell line \\
\hline Luminal A & ER+, PR \pm HER2- & MCF-7, T47D \\
Luminal B & ER+, PR \pm HER2+ & PR BT-474, ZR-75 \\
HER2+ & ER-, PR-, HER2+ & MDA-MB-453 \\
TNBC (Basal-like) & ER-, PR-, HER2- & BT-20, MDA-MB-468 \\
TNBC (Claudin-low) & ER-, PR-, HER2- & BT549, Hs578T, \\
& & MDA-MB-231 \\
\hline
\end{tabular}

TNBC: Triple-negative breast cancer; ER: estrogen receptor; PR: progesteron receptor.

\section{HDACs and their Mechanism of Action}

Today, several BC subtypes are treated with many different primary therapeutic protocols, but none of them uses epigenetic drugs, despite the fact that the interest for epigenetics in $\mathrm{BC}$ tumorgenesis is increasing $(12,13)$.

Gene regulation is affected by nucleosome packaging. Nucleosome is the organizing DNA structure that is consisted of about a 200 bp DNA coiled around an octameric core, consisted of histone proteins (14).

$\mathrm{N}$-terminal tails of histones extend outward from the nucleosomal core and are modified by the covalent addition of groups to the side chains of certain amino acids. These modifications, including methylation, acetylation, phosphorylation and the reverse processes, can change the secondary DNA structure. As a result, gene promoter regions become accessible or inaccessible to transcription factors (15).

Histone acetyltransferases (HATs) catalyze the reversible process of lysine acetylation at the $\varepsilon$-amino group of proteinogenic lysine residues. Histone acetylation neutralizes the positive charge of lysine residues, therefore is correlated to chromatin relaxation and active gene transcription (17). On the other hand, functional antagonists of HATs, histone deacetylases (HDACs) remove the acetyl groups (16), thus leading to compressed chromatin structure (heterochromatin), and subsequently suppressing gene transcription (18) (Figure 1). Except for the direct effect of acetylation on chromatin structure, gene regulation through acetylation is based on synergistic actions. The specific acetylation patterns on histone tails recruit further chromatin modulators that form corepressor or co-activator complexes.

Several human HDACs have been identified; recently HDACs have been classified into four classes in accordance to functional criteria and homology to yeast proteins (19). In general, HDACs can be divided into $\mathrm{Zn}^{2+}$-dependent classes (class I, II and IV) and NAD-dependent classes (class III). Class I is consisted of HDACs 1, 2, 3 and 8. Class II can be divided further into class IIa (HDAC4, 5, 7, and 9) and class IIb (HDAC6 and 10). Class III members, or sirtuins as they 


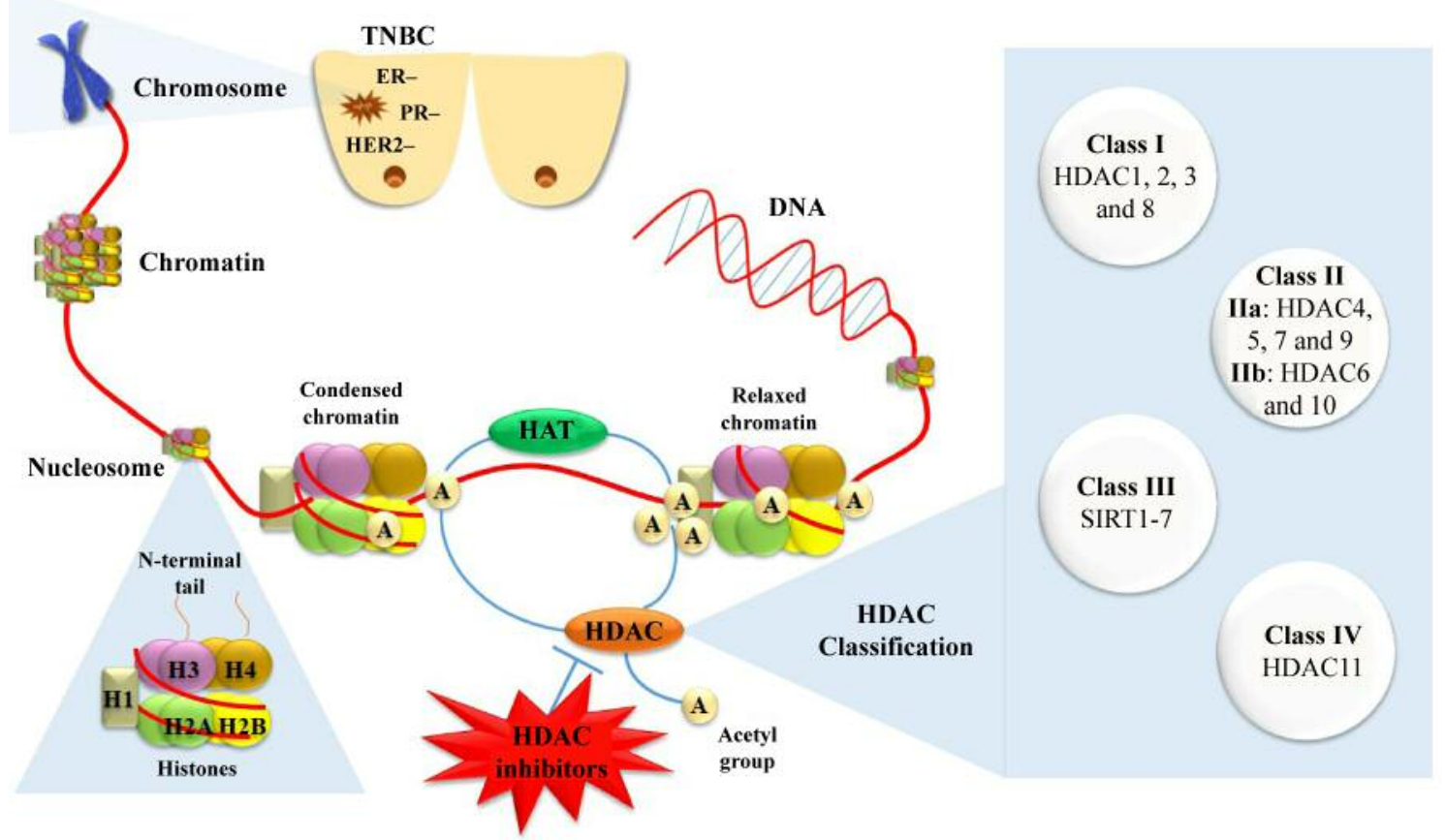

Figure 1. Therapeutic strategy targeting histone deacetylases against triple-negative breast cancer and histone deacetylase inhibitors classification. TNBC: Triple-negative breast cancer; HAT: histone acetyltransferases; HDAC: histone deacetylases.

are often called since they are homologous to silent information regulator 2 (SIR2) of Saccharomyces cerevisiae, consist of SIRT1-SIRT7. Finally, class IV has only one member, HDAC11 (20) (Figure 1).

\section{HDAC Inhibitors as Anti-cancer Agents}

HDAC inhibitors can be classified into four classes according to their chemical structure: a) hydroxamates (e.g. suberanilohydroxamic acid (SAHA)), b) benzamides (e.g. MS$275)$, c) cyclic peptides (e.g. romidepsin) and d) aliphatic acids (e.g. valproic acid). Alternatively, HDAC inhibitors can be classified according to their specificity for HDAC subtypes or classes. For example, SAHA and trichostatin A are pan-HDAC inhibitors, while MS-275 and romidepsin inhibit class I and valproic acid inhibits class I and IIa HDACs (21).

It is clear that both histone acetylation and deacetylation affect chromatin remodeling as strong epigenetic mechanisms. Interestingly, evidence from several reports indicates that HDAC levels are increased in certain cancer types (22-24). In addition, HDAC inhibitors have been reported to enhance the acetylation of histones, in tumor cells (25). Unlike other cytostatic-type compounds, HDAC inhibitors have been reported to exert much lower cytoxicity on normal cells, than on cancer cells. In general, HDAC inhibitors induce the inhibition of tumor growth and the apoptosis of cancer cells.
Clinical trials (phases I and II) have also demonstrated that HDAC inhibitors result in minor adverse effects in patients (15, 26-30). Their mechanism of action involves binding of their hydroxamate group to the zinc cation $\left(\mathrm{Zn}^{2+}\right)$ located in the HDAC cavity (31). Several clinical trials seemed to have a beneficial result. For instance, the US Food and Drug Administration has approved SAHA and romidepsin as regimen of cutaneous T-cell lymphoma $(29,31)$ and peripheral T-cell lymphoma (27) respectively. Moreover, panobinostat treatment is reported to be clinically successful against multiple myeloma (28).

In total, advanced stages of clinical trials have studied several HDAC inhibitors against many cancer types. However, concerning the TNBC field, studies have shown that, in general, HDAC inhibitors succeed clinically beneficial results as complementary treatment (e.g. SAHA and VPA), or in combination with cytotoxic drugs and ionizing radiation (Table II).

SAHA. SAHA or vorinostat is a pan-HDAC inhibitor that induces apoptosis in several types of haematological and solid tumor cells (32). Clinical investigations show that SAHA is a potent inhibitor against tumor types at doses that were well tolerated by patients (33).

According to a study in human TNBC cell lines, MDAMB-231 and inBT-549, SAHA significantly promotes in vitro motility via activation of epithelial-mesenchymal transition 
Table II. Histone deacetylase inhibitors and their action against triple-negative breast cancer.

\begin{tabular}{|c|c|c|}
\hline HDAC inhibitors & Co-treatment & Action \\
\hline \multirow[t]{8}{*}{ SAHA } & Alone & Promotion of EMT via HDAC8/FOXA1 signals \\
\hline & Olaparid & Inhibition of tumor growth, apoptotic + autophagic cell death \\
\hline & IR & Inhibition of tumor growth, DNA damage \\
\hline & Parthenolide & Nucleosome conformation, activation of caspase- 3 , relegation of beclin- 1 , inhibition of autophagy \\
\hline & Sorafenib & Apoptotic + autophagic cell death \\
\hline & Cisplatin & Inhibition of HDAC6, apoptosis, cell cycle arrest \\
\hline & Ferrocifen & Anti-proliferative activity \\
\hline & $\mathrm{NaB}$ & $\begin{array}{c}\text { Anti-proliferative activity, cell cycle arrest at } \mathrm{G}_{0} / \mathrm{G}_{1} \text { phase, apoptosis, decrease of } \\
\text { phosphorylation, protein and mRNA expression of wtp53 }\end{array}$ \\
\hline $\mathrm{NaB}$ & TSA & G6PDH activation, rising of oxygen consumption \\
\hline \multirow[t]{2}{*}{ Mocetinostat } & Alone & Inhibition of genes involved in cell cycle regulation \\
\hline & JQ1 & Decrease of cell viability, increase in the expression of USP17L5, decrease of Ras activity \\
\hline \multirow[t]{3}{*}{ Panobinostat } & Alone & $\begin{array}{l}\text { Apoptosis, anti-proliferative activity, inhibition of primary tumor volumes, increase of CDH1, } \\
\text { cell cycle arrest at } \mathrm{G}_{2} / \mathrm{M} \text { phase, restoration of ERa mRNA+ protein expression, anti-EMT effects }\end{array}$ \\
\hline & Salinomycin & Anti-proliferative activity, inhibition of breast cancer stem cell properties, suppression of ALDH1 activity \\
\hline & Chloroquine & Inhibition of tumor growth, increase in viability \\
\hline \multirow[t]{2}{*}{ Entinostat } & Alone & $\begin{array}{c}\text { Anti-EMT effects, increase of E-cadherin, inhibition of HDAC1, inhibition of cell migration, } \\
\text { prevention of metastasis }\end{array}$ \\
\hline & ATRA+Doxorubicin & Inhibition of tumor growth, inhibition of Topo II- $\beta$, silence of RAR- $\beta$ \\
\hline YCW1 & IR & Autophagic cell death, inhibition of BNIP3 \\
\hline Compound 2 & Alone & Anti-proliferative activity, target HDAC8 \\
\hline
\end{tabular}

HDAC: Histone deacetylases; SAHA: suberoylanilidehydroxamic acid; NaB: sodium butyrate; YCW1: [3-(2-(5-methoxy-1H-indol1yl)ethoxy)phenyl]-amide N-hydroxyamide; IR: ionizing radiation; TSA: trichostatin A; ATRA: all-trans retinoic acid; EMT: epithelial to mesenchymal transition; FOXA1; forkhead-box protein A1; G6PDH: glucose-6phosphate dehydrogenase; CDH1: cadherin; ERa: estrogen receptor a; ALDH1: aldehyde dehydrogenase 1 ; TopoII- $\beta$ : topoisomerase II- $\beta$; RAR- $\beta$ : retinoic acid receptor; BNIP3: BCL2/adenovirus E1B 19 kDa proteininteracting protein 3 .

(EMT) phenotype (34). This phenotype is known as the first and critical point for metastatic dissemination of cancer cells. Vimentin up-regulation and E-cadherin down-regulation are considered as markers of EMT $(35,36)$.

$\mathrm{Wu}$ et al. found that SAHA treatment induces the expression of the mesenchymal markers $\mathrm{N}$-Cadherin, Vimentin and Fibronectin, while decreases the expression of epithelial marker E-Cadherin. Nevertheless, SAHA treatment does not change neither the expression nor the nuclear translocation of transcription factors related to EMT. These factors were zinc finger proteins SNAI1 (SNAIL) and SNAI2 (SLUG), basic helix-loop-helix transcription factor Twist-related protein (TWIST) and Zinc finger E-box-binding homeobox (ZEB). As a result it seemed that these epithelial-mesenchymal transition related transcription factors are not involved in this process. Moreover, SAHA treatment decreased mRNA and protein expression of forkhead-box protein A 1 (FOXA1) (34). FOXA1, as a growth factor, mediates the hormonal response in BC $(37,38)$. When FOXAl is over-expressed, SAHA induced EMT of TNBC cells is limited.

Furthermore, in MDA-MB-231 and BT-549 cells, SAHAinduced down-regulation of FOXAl transcription and upregulation of $N$-cadherin and vimentin were attenuated by silencing of HDAC8, but not HDAC6 (34). Previous studies have suggested that HDAC6 and HDAC8 mediate the SAHA effects in BC cells $(39,40)$. HDAC8 lacks the conserved Cterminal domain (41), so it is a unique class I HDAC and it has a different expression profile from those of HDACs 1-3 (42). HDAC8 silencing does not change histone acetylation (43), but it has been assumed that it could act at certain promoter sites of FOXA1. Based on this evidence, researchers claimed that HDAC8/FOXAl signals motivated by SAHA treatment induce the EMT of TNBC cells (34).

As it is known, HDACs participate at the homologous recombination repair pathway of DNA, given the fact that they regulate the expression of genes related to this procedure (15). Studies have shown that ADP-ribose (poly) polymerase (PARP) inhibitors, such as olaparid, could be used as anticancer treatment). Min et al. have searched whether SAHA treatment enhances the anti-tumor effect of poly (ADP-ribose) polymerase (PARP) inhibitors in TNBC cells by blocking the homologous recombination repair pathway (46). Investigators used MDA-MB-157, -231, -453, -468 and BT-549 human cells and found that combinational treatment with olaparid and SAHA suppressed the proliferative signaling pathway and promoted inhibition of tumor growth, in comparison to 
olaparid or SAHA treatment alone. An in vivo study of a MDA-MB-231 xenograft model confirmed this evidence. Moreover, this combination seemed to induce both apoptotic and autophagic cell death, thus enhanced the cytotoxic effects of these inhibitors (46). Further studies could examine more combined treatments of PARP inhibitors with other HDAC inhibitors in order to improve therapeutic approaches for TNBC patients.

Furthermore, it is known that the majority of deaths in TNBC patients are not due to the primary tumors, but to metastases. An in vitro study on MDA-MB-231 and 4T1 (a mouse TNBC cell line) cell lines for the investigation of the effects of ionizing radiation (IR) and SAHA co-treatment, indicated that the combination was therapeutically more effective in a statistically significant way, than IR or SAHA alone. Tumor growth was also inhibited, in vivo, in an orthotopic BC mouse model (47). In addition, this combination increased DNA damage through the inhibition of DNA repair proteins. Concerning SAHA treatment in 4T1 cells, it led to inhibition of BC cell migration and invasion, via the inhibition of matrix metalloproteinase-9 (MMP-9) activity.

In general, evidence shows, in several cancer types, MMPs mediate the invasion and metastasis (48). MMP-9 participates at the degradation of type IV collagen and its over-expression has been found to be associated with invasion and metastatic potential in many types of carcinomas (49-53). In total, evidence indicates that SAHA could serve as a radiosensitizer against TNBC (47).

Also, in the same study, an in vivo experimental metastasis mouse model was used and showed that SAHA treatment inhibited lung metastasis and enhanced radiosensitivity (47). Concerning metastases, another study of an in vivo model of TNBC has reported that SAHA treatment is involved in the induction of DNA double-strand breaks suppressing brain metastatic colonization by $62 \%$ (54). Further studies that combine SAHA with DNA active drugs or radiation are needed in order to investigate thoroughly their actions against metastases.

Carlisi et al. studied the combination of SAHA and parthenolide (PN) (55). The principal bioactive sesquiterpene lactone component of feverfew Tanacetum parthenium, PN, was found to induce tumor inhibition on many cancer types, such as osteosarcoma, melanoma (56) and prostatic (57), pancreatic (58), colorectal (59) cancers. At the same time it showed low toxicity against normal cells. PN acts cytotoxically on MDA-MB231 cells, but at low doses it is not effective $(60,61)$. Investigators have combined PN and SAHA in order to overcome the PN's deficiency (55).

They claimed that pre-treatment of MDA-MB231 cells with SAHA sensitized the cells to the cytotoxic effect of PN (62), so PN and SAHA acted synergistically in order to fight against TNBC cells (55). Moreover, they demonstrated that SAHA treatment leads to acetylation of lysine residues in the $\mathrm{NH}_{2-}$ terminal tails of histones $\mathrm{H} 3$ and $\mathrm{H} 4$ and these findings were in accordance to other studies $(63,64)$. Furthermore, investigators claimed that there is an association between this histone hyperacetylation provoked by SAHA or SAHA and PN treatment and the up-regulation of tumor suppressor factors p21 and p27, as well as down-regulation of fundamental survival proteins Bcl-2 (55). These results have also been confirmed by another study (65). This evidence demonstrates that epigenetic actions could induce the alterations in the expression of these proteins.

Investigators have also studied the production of reactive oxygen species (ROS) and the autophagic process and they have found that SAHA treatment urges both processes. Both ROS generation and autophagy are reduced by two NADPH oxidase family (NOX) inhibitors - Nox enzymes are major ROS producers-, apocynin and diphenyleneiodonium chloride (DPI). Therefore, it was proposed that SAHA primarily induced NOX to increase the production of ROS, which led to activation of autophagy (55). Another study has shown that SAHA stimulates autophagy in tumor cells (66). When they added PN, SAHA's results on ROS generation and autophagic process were diminished, while they observed a potent activation of apoptosis.

Finally, it has been found that SAHA and PN combined therapy induced a decrease of the expression levels of beclin-1, a protein involved in autophagosome formation (55). Previous studies have shown that beclin-1 is cleaved by caspases (67). $N$-terminal cleavage fragment of beclin-1 suppresses autophagy, while its C-terminal cleavage fragment promotes the release of cytochrome $\mathrm{C}$ from mitochondria (68). As an extension to the above mentioned finding, investigators have claimed that SAHA/PN combination treatment relegates beclin-1 by activating caspase-3. This event could inhibit SAHA- induced autophagy and the release of cytochrome $\mathrm{C}$ (55). Taken together this evidence, it could be implied that SAHA/PN co-treatment could be a candidate for TNBC therapy.

A recent study on MDA-MB-231 cells used SAHA in comparison to a kinase inhibitor and found that this cotreatment induces cell death. An important fact was that cell death was induced by both autophagy and apoptosis (69). These results were confirmed by Zhang et al., who used SAHA and the antiangiogenic kinase inhibitor Sorafenib in epithelial tumor cell types and found that this treatment suppressed the expression of anti-apoptotic proteins and increased the activation of CD95 extrinsic apoptotic and lysosomal protease pathways. So this combination has been found to interact synergistically against liver, kidney, and pancreatic tumor cells in vitro (70). These studies indicate that the combination of a kinase and an HDAC inhibitor is a promising treatment modality for the prevention or therapy of aggressive cancer types, especially TNBC.

The effects of HDAC inhibitors (VPA and SAHA) and cisplatin (CDDP), a chemotherapeutic agent, co-treatment 
against several types of $\mathrm{BC}$ cells have been explored using an isobolographic method $(71,72)$. This combination achieved to reduce the doses of the compounds and to be therapeutically beneficial for head and neck squamous cell carcinomas (26, $73)$ and $\mathrm{BC}$ in vitro $(74,75)$. This study also showed that in MDA-MB231 cells, the combination of the CDDP and VPA at the ratio of 1:1 induced antagonistic interactions, while CDDP and SAHA co-treatment induced synergistic interactions (71). According to the investigators, this could be explained by the fact that SAHA is a potent inhibitor of the HDAC6 activity compared to VPA (26). Many nuclear proteins, like the transcription factor forkhead boxp3 (FOXP3) and the DNA repair factor KU70, are substrates of HDAC6, which is recruited by RNA polymerase II to chromatin in order to suppress the cycles of acetylation/deacetylation. This procedure enables the transcription and transfers cytotoxic poly-ubiquitinylated proteins into autophagosomes (76). All these mechanisms of HDAC6 action and its potential inhibition by SAHA could explain the hypothesis.

Moreover, it has been reported that CDDP/HDAC inhibitor co-treatment induces apoptosis and cell-cycle arrest of TNBC cells (71). Further research in vivo is necessary in order to use this promising combination therapy in TNBC clinical trials.

A recent study has described a new family of hybrid compounds that combine particular structural motifs of tamoxifen (TAM), ferrocifen (FcTAM) and SAHA (77). Ferrocenyl group $(\mathrm{Fc})$ is reported to act as a redox antenna for phenol oxidation via an intra-molecular mechanism (78-80). They have found that ferrocene derivatives are extremely more active than organic analogs in MDA-MB-231 cells and hormone-dependent MCF-7 BC cell lines. FcTAM improved its inhibitory activity by replacing its 3-(dimethylamino) propan-1oxy group with an 8-hydroxyamino-8-oxooctanamido or an 8-amino-8-oxooctanamido group. In MDA-MB-231 BC cells, FcTAM-SAHA treatment exerted better antiproliferative effects than SAHA treatment alone (77). Interestingly, the organometallic compounds induced the expression of p21waf1/cip1 gene in MCF-7 cells in accordance with their antiproliferative activity (77). Further research on the field of organometallic moiety could contribute to a more proper treatment against TNBC.

Sodium Butyrate and SAHA. Sodium butyrate $(\mathrm{NaB})$ is shown to exhibit beneficial anticancer ability (81). It has the potential to relax the chromatin structure, allowing easier access to transcription-related proteins. These abilities render $\mathrm{NaB}$ a potent treatment against several types of solid tumor $(82,83)$. A study in MDA-MB-231 and BT-549 cell lines using various concentrations of $\mathrm{NaB}$ and SAHA for $24 \mathrm{~h}$ revealed that these inhibitors suppress cell proliferation, arrest cell cycle at $G_{0} / G_{1}$ phase, and finally are involved in mitochondrial-related apoptosis. Moreover, both SAHA and $\mathrm{NaB}$ treatment decreased the phosphorylation, and also the mRNA and protein levels of mutant p53 (mtp53), while neither of these compounds had anti-proliferative effects on wild type p53 (wtp53) via time and dose dependent manners (84). p53 gene has been reported as the most frequently mutated gene in $\mathrm{BC}$ (85). Approximately, $62 \%$ of the basal-like TNBC and $43 \%$ of the non-basal-like TNBC have mutations in the mtp53 (86).

These data urged the investigators to report that the inhibition occurs during the transcription, given that the transcription of the precursor p53 is down-regulated more rapidly (less than $2 \mathrm{~h}$ ) and aggressively than that of mature p53. Also, the transcription of mtp53 is inhibited by the silencing of HDAC8, while not of HDAC6 (84). Both HDAC6 and HDAC8 are previously reported to mediate the down-regulation of p53 induced by HDAC inhibitors $(40,87)$.

Moreover, both SAHA and NaB reduced the binding of transcription factor Yin Yang 1 (YY1) with the -102 to -96 position of human p53 promoter. Interestingly, silencing of YY1 significantly inhibits the mtp53 transcription (83). YY1 is suggested to be over-expressed in BC cells and to be a key molecule in BC progression. Knockdown of YY1 led to suppression of the clonogenicity, migration, invasion and tumor formation of BC cells (88).

Based on the above, researchers have found that both SAHA and NaB reduced the association of HDAC8 and YY1. As a result, acetylation of residues 170-200 of YY1 was enhanced, leading to decreased YY1 transcription and finally, inhibition of the YY1- induced p53 transcription (84). In total, this study showed that not only SAHA and $\mathrm{NaB}$ treatment could be very promising for TNBC patients, but also HDAC8/YY1/mtp53 signals could become an important target for TNBC therapy.

Trichostatin A and NaB. Trichostatin A (TSA) is an antifungal antibiotic, found in cultured mammalian cells and, at low nanomolar concentrations, in fractionated cell nuclear extracts. In general, as an HDAC inhibitor, TSA not only suppresses HDAC activity, but also leads to cell-cycle arrest in $G_{1}$ and $\mathrm{G}_{2}$ phase, induces cell differentiation as well as the reversion of transformed cells in vitro (89).

A study of the effect of $\mathrm{NaB}$ and TSA on viability of nontumorgenic MCF10A cells and of MCF-7, T-47D and MDAMB-231 cell lines (90) has found that MCF10A cells were minimum affected by elevated doses of these HDAC inhibitors while the other tested cell lines were extremely sensitive to treatment with both $\mathrm{NaB}$ and TSA. Concerning the TNBC cell line (MDA-MB-231), NaB treatment significantly enhanced the activity of pyruvate kinase, but it neither induced an attenuation of glycolysis, nor enhanced the activity of lactate dehydrogenase, as it happened in T-47 D cells. Furthermore, in both T-47D and MDA-MB-231 cells, the rate-limiting enzyme of the pentose phosphate pathway, Glucose-6phosphate dehydrogenase (G6PDH) was activated by $\mathrm{NaB}$ treatment, while in MCF-7 cells, G6PDH activity was 
inhibited. Finally, both $\mathrm{NaB}$ and TSA in MDA-MB-231 and T-47D cells significantly raised the oxygen consumption. These data show that mitochondria might occupy a key role in metastasis (90). Further research is required in order to understand the pathways of action of these inhibitors and then target the proper signals to suppress the specific BC type.

Mocetinostat. Mocetinostat is a class I HDAC inhibitor that is associated with the reversion of cardiac fibrosis (91). Recently, mocetinostat was reported to have promising antitumor activities against various types of cancer cell lines and tumor xenografts in nude mice, as it is related to apoptosis (92-94). A study showed that mocetinostat inhibits the growth of colon cancer cells via the up-regulation of WNT ligand DKK-1 expression (95). Also, in B-cell chronic lymphocytic leukemia cells, it has been shown to lead to apoptosis, as it decreases the expression of Mcl-1 protein and it induces Bax translocation to mitochondria (96). Another study has shown that mocetinostat inhibits the proliferation of prostate cancer cells (93).

Borbely et al. studied the combination of mocetinostat and JQ1 in MDA-MB-231, BT549, MCF-7 and T47-D cells (97). JQ1 is a bromodomain and extra-C terminal (BET) inhibitor and is reported to participate in the expression of oncogenes and tumor suppressor genes. JQ1 is in pre-clinical testing for the treatment of hematological malignancies and neuroblastoma (98-100). Researchers found that either JQ1 or mocetinostat treatment alone, inhibited the expression of genes involved in cell cycle regulation. Interestingly, the combination of JQ1 and mocetinostat decreased even more cell viability as the compounds acted synergistically.

Furthermore, combination treatment was associated with a sharp increase in the expression of many members of the ubiquitin-specific protease 17 (USP17) family of deubiquitinating enzymes (97). Previous studies have reported that USP17 regulates Ras/MAPK signaling partly through the regulation of the RCE1 (101). It is known that the Ras/MAPK pathway is involved in BC progression (102). The activity of this pathway has been tested and it was found that the expression of USP17L5 protein was increased, when at the same time Ras activity was decreased. In other words, USP17 enzymes attenuated the Ras/MAPK pathway and cell viability was suppressed. On the other hand siRNA-mediated depletion of USP17, decreased the cytoxicity, indicating that the Ras/MAPK signaling pathway is involved in the synergistic effect of the combinational treatment (97). All these data show that the combination of HDAC and BET inhibitors could be used as potential therapeutic strategy for $\mathrm{BC}$, given that it reduces the viability of TNBC cells, through induction of USP17.

Panobinostat. Panobinostat (LBH589) is a pan-HDAC inhibitor. It has the ability to block several pathways related to cancer and reverse epigenetic events related to cancer progression (103). Its anti-cancer effects have been observed in hematologic, lung, breast, ovarian, thyroid and prostate malignancies (104). Recently panobinostat was approved for treatment of multiple myeloma with tumor progression after immunomodulating agents and bortezomib (105).

Interestingly, a study has reported significant action of panobinostat against the TNBC, as it exerted anti-proliferative action, provoked apoptosis and inhibited the primary tumor volumes of TNBC xenografts (106). Also in the same study, in vitro and in vivo results have shown that treatment with panobinostat increases significantly the epithelial cell marker CDH1. In general, the expression of EMT markers, such as epithelial-cadherin (CDH1), neuronal-cadherin (CDH2), vimentin (VIM), zinc finger E-box binding homeobox 1 (ZEB1) and 2 (ZEB2), has been associated with poor prognosis of BC patients (107-109). As a result, these markers have become attractive targets for the confrontation of metastasis.

In a recent study it has been tested whether panobinostat has the ability to inhibit the migration, invasion, and metastasis of MDA-MB-231 and BT-549 cell lines, by suppressing EMT (110). In TNBC cells, panobinostat has been reported to inhibit the expression of genes associated to EMT and to induce the expression of CDH1, while these results were not found in luminal A or basal BC cell lines (106). This study has also reported very important results about panobinostat effects on MDA-MB-231 and BT-549 cells, as it augmented histone acetylation, while suppressed the cell proliferation and viability. It led to cell cycle arrest at $\mathrm{G}_{2} / \mathrm{M}$ phase with a simultaneous decrease in $\mathrm{S}$ phase. Moreover, panobinostat induced apoptosis at $24 \mathrm{~h}$. In addition, treatment of ER-negative breast cancer cells (MDA-MB-231 and MDA-MB-435) with panobinostat for $24 \mathrm{~h}$ resulted in restoration of ER $\alpha \mathrm{mRNA}$ and protein expression. However, reactivation of ER $\alpha$ expression was not due to changes in the methylation profile of $\mathrm{CpG}$ island within ER promoter region. Interestingly, after at least $96 \mathrm{~h}$ from termination of panobinostat treatment, the expression of ER $\alpha$ mRNA was maintained. Panobinostat treatment released DNA (cytosine-5)-methyltransferase 1 (DNMT1), HDAC1, and the H3 lysine 9 (H3-K9) methyltransferase SUV39H1 from the ER promoter. Investigators claimed that these changes altered the chromatin state to active, characterized by increased the levels of acetylated $\mathrm{H} 3$ and $\mathrm{H} 4$, decreased methylated $\mathrm{H} 3-\mathrm{K} 9$ and false binding of heterochromatin protein 1 (HP1 alpha) at the promoter (111).

Furthermore, Rhodes et al. compared panobinostat to other HDAC inhibitors (SAHA, TMP269) and found that panobinostat has much more potent anti-EMT effects than the other inhibitors (110). In vitro research showed that changes in EMT-related gene expression were associated with the suppression of cell migration and invasion. Also, in a xenograft model these alterations have induced a statistically significant inhibition of metastasis of TNBC cells to both brain and lung. Except for $\mathrm{CDH} 1$ expression, panobinostat has 
induced the suppression of multiple predominant pro-EMT genes including $Z E B 1$ and $Z E B 2$. In addition, when investigators forced exogenous expression of $Z E B 1$ or $Z E B 2$, the inhibitory effects of panobinostat on cell migration, invasion, and CDH1 expression were reversed (110).

It has been recently reported that ZEBs recruit Class I HDACs $(48,112,113)$. Given the fact that panobinostat can act against Class I, II and IV HDACs, in addition to inhibition of ZEB expression, panobinostat has the ability to prevent ZEB-mediated repression of CDH1.

However, it is probably the repression of ZEB2 that regulates the effects of panobinostat on tumor genesis, as ZEB1 expression alone was not sufficient to overcome the actions of panobinostat on CDH1 expression (110). To sum up, it is critical to study panobinostat as a novel therapeutic to target the aggressive and metastatic nature of TNBC, as panobinostat is claimed to inhibit both TNBC primary tumor genesis and the metastasis of TNBC cells.

Another study has confirmed these findings, given that it was found that in MDA-MB231 cells independent of estrogen receptor expression, panobinostat induced $\mathrm{CDH} 1$ expression (114). Panobinostat was reported to induce the expression of $\mathrm{CDH} 1$ and reduce the migration and invasion of TNBC cells. Researchers claimed that panobinostat by-passed the CDH1 transcriptional repressors (Snail, Slug), while the ERa expression and pathway were not affected.

Another combination that has been studied on TNBC cell lines (HCC1937 and MDA-MB-231) is co-treatment of panobinostat and salinomycin (115). Salinomycin is an antibiotic that has been used in farm animals (116) and it has been associated with the inhibition of BC stem cells in TNBC $(117,118)$. Also, studies in glioblastoma have shown that cotreatment of salomycin and HDAC inhibitors induced the death of stem-like glioblastoma cells (119). Kai et al. have reported that panobinostat and salinomycin acted synergistically and inhibited the TNBC cell proliferation (115).

HDAC inhibitors have been found to be beneficial in BC therapy, as they target BC stem cells, have anti-proliferative effects on aldehyde dehydrogenase 1 (ALDH1)-positive cells, and suppress the formation of BC mammospheres (120). Also, ALDH1 has been associated with TNBC, so ALDH1 can be used as a BC stem cell marker in TNBC $(121,122)$. Based on these facts, Kai et al. determined the activity of panobinostat on TNBC cells with BC stem cell properties (115). Cotreatment of panobinostat and salinomycin inhibited the BC stem cell properties, as the self-renewal capacity and ALDH1 activity were suppressed. Moreover, this combinational treatment inhibited growth of ALDH1-positive cells, induced apoptosis, arrested cell cycle and regulated EMT in BC stem cells (115). We can assume that further research is needed, given that co-treatment of panobinostat with salinomycin in TNBC is claimed to provide an effective targeted therapy for patients with TNBC.
A study on MDA-MB-231cells investigated the in vitro and in vivo effect of co-treatment of panobinostat with the autophagy inhibitor chloroquine (123). First of all, panobinostat treatment disrupted the hsp90/HDAC6/HSF1/p97 complex $(124,125)$ and induced a heat shock response mediated by heat shock factor protein 1 (HSF1). This abruption of the HSF1 from the multiprotein comlex is reported to lead to HSF1 phosphorylation, trimerization and nuclear translocation $(125,126)$. Moreover, panobinostat treatment induced endoplasmic reticulum stress response and autophagy (123), evidence also supported by previous research (127-129). Combinational treatment of panobinostat with chloroquine was found to significantly enhance both the in vivo and the in vitro effect of panobinostat, given the fact that it inhibited tumor growth and increased viability of MDAMB-231 xenografts (123).

Therefore, panobinostat could be used for treatment of aggressive $\mathrm{BC}$ that is resistant to hormonal therapy. We propose that panobinostat should be tested either in monotherapy, or in combination with known anti-cancer agents, like trastuzumab, capecitabine, lapatinib, or paclitaxel.

Entinostat. Previous studies have reported that retinoic acid and its products, such as all-trans retinoic acid (ATRA), urge the differentiation of multiple types of stem cells, including the stem cells that exist in BC $(130,131)$. On the other hand, ATRA has been used in a clinical trial and its efficacy was limited (132), possibly because of the epigenetic knock-out of the retinoic acid receptor (RAR)- $\beta$ (133). Recent studies have shown that HDAC inhibitors have the ability to re-express RAR- $\beta$, so they restore the sensitivity of the cells to treatment (134-136). It has been reported that co-treatment of HDAC inhibitors with either doxorubicin or retinoids increased the cytoxicity against cancer cells $(75,137)$.

A novel study has examined the effects of co-treatment with entinostat (MS-275), which is a selective inhibitor of class I HDACs, ATRA, and doxorubicin and reported that TNBC cell growth was inhibited in xenografts and killed tumor cells and in cell cultures (138). Given the fact that direct binding of topoisomerase II- $\beta$ (TopoII- $\beta$ ) to RAR- $\beta$ promoter has been reported in acute pro-myelocytic leukemia cells (139), investigators have searched that path and found that entinostat and doxorubicin treatment suppressed the expression of Topo II- $\beta$. As a result, RAR- $\beta$ expression was silenced. It was demonstrated that this co-treatment achieved significant tumor suppression in TNBC, as entinostat urges the cytoxicity mediated by doxorubicin and the differentiation mediated by retinoid (138).

As we mentioned, in metastatic cell lines and invasive BCs E-cadherin is silenced epigenetically and EMT phenotype is reported to be the critical step in the beginning of metastasis (140-142). In MDA-MB-231 and Hs578T cells, entinostat treatment has been reported to reverse the EMT phenotype 
(143). These cell lines have lost the expression of E-cadherin, while they highly express mesenchymal markers such as $\mathrm{N}$ cadherin and vimentin along with transcriptional repressors such as Twist and Snail (144-147). Treatment with entinostat increased the transcription of E-cadherin, while the mRNA expression of N-cadherin was decreased. Chromatin immunoprecipitation analysis demonstrated that E-cadherin's promoter was activated due to a decrease in the association of TWIST and SNAIL with E-cadherin promoter (143). In a previous study, it has been reported that HDAC1 activity is required for the SNAIL-mediated repression of E-cadherin (145), so investigators studied the activity of HDAC1 and found that entinostat inhibits HDAC1, thus the repression of E-cadherin is reversed. An in vitro study has shown that entinostat inhibited cell migration. Moreover, there was observed an increase of vimentin phosphorylation levels, as well as changes in vimentin filaments. Interestingly, the increased phosphorylation of vimentin led to suppression of the formation of microtentacles based on tubulin (143), which are known to help floating cells attach to other surfaces (148).

We should also mention that a subset of cells within a breast tumor may cause escape from the primary site. These cells are named as tumor-initiating cells (TICs). TICs produce progenitor cells, which cannot self-renew, but they may comprise the greater part of the tumor (149). Entinostat treatment on TNBC cells has been shown to decrease the level of TICs, therefore entinostat might be used to prevent development of metastasis (150).

It is apparent that the ability of entinostat to reverse the EMT phenotype and reduce the migration of TNBC cells, as it reduces the attachment of floating cancer cells to new surfaces, render it a promising therapeutic agent against metastasis.

$Y C W 1$. The octanedioic acid [3-(2-(5-methoxy-1H-indol1yl)ethoxy)phenyl]-amide $N$-hydroxyamide (YCW1) is a novel HDAC inhibitor that has been developped by structurebased analyses $(151,152)$. Researchers have tested the cotreatment with YCW1 and ionizing radiation (IR) in a murine and a human TNBC cell line, 4 T1, and MDA-MB-231, respectively. This combination was shown to increase autophagy and endoplasmic reticulum stress, so these compounds acted as a cytotoxic. Interistingly, in comparison to the effects of SAHA, YCW1 significantly enhanced toxicity. Study in an orthotopic BC mouse model confirmed these results (153). Therefore, co-treatment with IR and YCW1 induced autophagic cell death.

$N$-(2-Hydroxyphenyl)-2propylpentanamide. $N$-(2-Hydroxyphenyl)-2propylpentanamide (Compound 2) is an aryl derivative of valproic acid. These derivatives are produced by combining valproic acid and the arylamine core of SAHA with different substituents at its carboxyl group. Compound 2 has exerted the most promising results between other derivatives that were submitted to docking simulations. In vitro studies against HeLa, rhabdomyosarcoma and BC cells lines have shown that compound 2 was the best anticancer agent (154). Interestingly, it was effective against TNBC cells. It seemed that compound 2 targeted HDAC8. In addition, in vitro studies have shown that compound 2 inhibited cancer cell proliferation at a much lower concentration, compared to valproic acid (154).

\section{Uncommon Results}

Unfortunately, despite the promising results in several preclinical trials, when HDAC inhibitors are used as single agents, they failed to be clinically beneficial against solid tumors (33). For instance, in the field of metastatic BC, SAHA treatment in 14 patients failed to achieve adequate single-agent activity (155). Moreover, de Cremoux et al. have used different HDAC inhibitors (SAHA, panobinostat, abexinostat) in MDA-MB231, Hs 578T and SUM149 human cell lines and found that despite the cytotoxicity of both of these inhibitors Estrogen receptor 1 (ESR1) and estrogen receptor 2 (ESR2) genes were not re-expressed in vitro (156). Xenograft studies with abexinostat treatment for three consecutive days did not induce the expression of ESR1/ESR1 related genes or of ERa protein. In addition, intra-tumor $\mathrm{H} 3$ acetylation was observed (156). Another study in MDA-MB231 and SKBR3 lines treated with SAHA or valproic acid for $48 \mathrm{~h}$, showed minimal or no alterations in ERa or in ERb mRNa and protein (157). Also, different HDAC inhibitors have been shown to cause different effects on luminal and mesenchymal-like breast cancer cells, either elevating histone acetylation or showing no effects (158).

\section{Conclusion}

TNBC is a serious subtype of BC that is correlated with poor prognosis due to the high proliferation rate. New therapeutic strategies are needed in order to cure TNBC. Epigenetic mutations are associated with repression of $\mathrm{BC}$ development and therapy resistance.

Between all the epigenetic treatments, HDAC inhibitors represent the first successful anti-cancer epigenetic therapy. Studies show that they affect positively the therapy of subtypes of hematological malignancies. However, it is still unclear how effective they are against solid tumors (159).

Nevertheless, the majority of studies in the field of TNBC therapy tend to combine HDAC inhibitors with kinase inhibitors, autophagy inhibitors, antibiotics, chemotherapy, IR, or even two HDAC inhibitors treatment in order to enhance their efficacy against $\operatorname{TNBC}(47,69,71,84,115,123,153)$. In the majority of the studies, co-treatment of an HDAC inhibitor with another compound induced the inhibition of tumor growth and showed anti-proliferative effects (46, 47, 
$77,84,115,123,138,154)$. Also, several HDAC inhibitors are assosiated not only with autophagic cell death, but also apoptosis $(44,55,70,71,84,97,153)$. Interestingly, many studies have found that HDAC inhibitors have the ability to convert ER-negative tumors to ER-positive tumors $(111,160$, 161). Finally, a recent study showed that entinostat treatment can prevent the metastasis (143).

However, as we mentioned above, we should not forget that there are several studies in the pertinent literature with contradictory results (155-157). These unexpected studies reveal the necessity for further investigation in the field of HDAC inhibitors against TNBC cancer. We should understand the nature of the molecular basis of the selectivity of HDAC inhibitors and which are the proper combining treatments in order to find more clinically beneficial treatment against TNBC.

\section{Conflicts of Interest}

The Authors declare that they do not have any conflict of interest.

\section{Acknowledgements}

Christos Damaskos would like to express his gratitude to his teacher, Spyridon Garmpis who not only selflessly taught him, but also his actions inspired him to learn more, do more and become better.

\section{References}

1 Antoniou AC and Easton DF: Models of genetic susceptibility to breast cancer. Oncogene 25: 5898-5905, 2006.

2 Rivenbark AG, O'Connor SM and Coleman WB: Molecular and cellular heterogeneity in breast cancer: challenges for personalized medicine. Am J Pathol 183: 1113-1124, 2013.

3 Nyante SJ, Lee SS, Benefield TS, Hoots TN and Henderson LM: The association between mammographic calcifications and breast cancer prognostic factors in a population-based registry cohort. Cancer 123: 219-227, 2017.

4 DeSantis CE, Bray F, Ferlay J, Lortet-Tieulent J, Anderson BO and Jemal A: International variation in female breast cancer incidence and mortality rates. Cancer Epidemiol Biomarkers Prev 24: 1495-1506, 2015.

5 Claude-Taupin A, Boyer-Guittaut M, Delage-Mourroux R and Hervouet E: Use of epigenetic modulators as a powerful adjuvant for breast cancer therapies. Methods Mol Biol 1238: 487-509, 2015.

6 Perou CM, Sørlie T, Eisen MB, van de Rijn M, Jeffrey SS, Rees CA, Pollack JR, Ross DT, Johnsen H, Akslen LA, Fluge O, Pergamenschikov A, Williams C, Zhu SX, Lønning PE, Børresen-Dale AL, Brown PO and Botstein D: Molecular portraits of human breast tumours. Nature 406: 747-752, 2000.

7 Holliday DL and Speirs V: Choosing the right cell line for breast cancer research. Breast Cancer Res 13: 215, 2011.

8 Neve RM, Chin K, Fridlyand J, Yeh J, Baehner FL, Fevr T, Clark L, Bayani N, Coppe JP, Tong F, Speed T, Spellman PT, DeVries S, Lapuk A, Wang NJ, Kuo WL, Stilwell JL, Pinkel D, Albertson DG, Waldman FM, McCormick F, Dickson RB, Johnson MD,
Lippman M, Ethier S, Gazdar A and Gray JW: A collection of breast cancer cell lines for the study of functionally distinct cancer subtypes. Cancer Cell 10: 515-527, 2006.

9 Bernhardt SM, Dasari P, Walsh D, Townsend AR, Price TJ and Ingman WV: Hormonal Modulation of Breast Cancer Gene Expression: Implications for Intrinsic Subtyping in Premenopausal Women. Front Oncol 6: 241, 2016.

10 Mohamed A, Krajewski K, Cakar B and Ma CX: Targeted therapy for breast cancer. Am J Pathol 183: 1096-1112, 2013.

11 Prat A, Parker JS, Karginova O, Fan C, Livasy C, Herschkowitz JI, He $\mathrm{X}$ and Perou CM: Phenotypic and molecular characterization of the claudin-low intrinsic subtype of breast cancer. Breast Cancer Res 12: R68, 2010.

12 Marks DL, Olson RL and Fernandez-Zapico ME: Epigenetic control of the tumor microenvironment. Epigenomics 8: 6711687, 2016.

13 Jones P: The cancer epigenome. Genome 56: 540-541, 2013.

14 Rando OJ and Ahmad K: Rules and regulation in the primary structure of chromatin. Curr Opin Cell Biol 19: 250-256, 2007.

15 Woo YM: Epigenetic regulation in cystogenesis. Adv Exp Med Biol 933: 59-68, 2016.

16 Kuo $\mathrm{MH}$ and Allis CD: Roles of histone acetyltransferases and deacetylases in gene regulation. Bioessays 20: 615-626, 1998.

17 Kouzarides T: Chromatin modifications and their function. Cell 128: 693-705, 2007

18 Haberland M, Montgomery RL and Olson EN: The many roles of histone deacetylases in development and physiology: implications for disease and therapy. Nat Rev Genet 10: 32-42, 2009.

19 Trapp J and Jung M: The role of NAD+ dependent histone deacetylases (sirtuins) in ageing. Curr Drug Targets 7: 15531560, 2006.

20 Olzscha H, Sheikh S and La Thangue NB: Deacetylation of chromatin and gene expression regulation: a new target for epigenetic therapy. Crit Rev Oncog 20: 1-17, 2015.

21 Marks PA: The clinical development of histone deacetylase inhibitors as targeted anticancer drugs. Expert Opin Investig Drugs 19: 1049-1066, 2010.

22 Zhang Z, Yamashita H, Toyama T, Sugiura H, Ando Y, Mita K, Hamaguchi M, Hara Y, Kobayashi S and Iwase H: Quantitation of HDAC1 mRNA expression in invasive carcinoma of the breast. Breast Cancer Res Treat 94: 11-16, 2005.

23 Stojanovic N, Hassan Z, Wirth M, Wenzel P, Beyer M, Schäfer C, Brand P, Kroemer A, Stauber RH, Schmid RM, Arlt A, Sellmer A, Mahboobi S, Rad R, Reichert M, Saur D, Krämer OH and Schneider G: HDAC1 and HDAC2 integrate the expression of p53 mutants in pancreatic cancer. Oncogene 36: 1804-1815, 2017.

24 Li A, Liu Z, Li M, Zhou S, Xu Y, Xiao Y and Yang W: HDAC5, a potential therapeutic target and prognostic biomarker, promotes proliferation, invasion and migration in human breast cancer. Oncotarget 7: 37966-37978, 2016.

25 New M, Olzscha H and La Thangue NB: HDAC inhibitor-based therapies: can we interpret the code? Mol Oncol 6: 637-656, 2012.

26 Lee JH, Choy ML, Ngo L, Foster SS and Marks PA: Histone deacetylase inhibitor induces DNA damage, which normal but not transformed cells can repair. Proc Natl Acad Sci USA 107: 14639-14644, 2010.

27 Barbarotta L and Hurley K: Romidepsin for the treatment of peripheral T-cell lymphoma. J Adv Pract Oncol 6: 22-36, 2015. 
28 Libby EN, Becker PS, Burwick N, Green DJ, Holmberg L and Bensinger WI: Panobinostat: a review of trial results and future prospects in multiple myeloma. Expert Rev Hematol 8: 9-18, 2015.

29 Mann BS, Johnson JR, He K, Sridhara R, Abraham S, Booth BP, Verbois L, Morse DE, Jee JM, Pope S, Harapanhalli RS, Dagher R, Farrell A, Justice R and Pazdur R: Vorinostat for treatment of cutaneous manifestations of advanced primary cutaneous T-cell lymphoma. Clin Cancer Res 13: 2318-2322, 2007.

30 Damaskos C, Garmpis N, Valsami S, Spartalis E, Antoniou EA, Tomos P, Karamaroudis S, Zoumpou T, Pergialiotis V, Stergios K, Michaelides C, Kontzoglou K, Perrea D, Nikiteas N and Dimitroulis D: Histone deacetylase inhibitors: A Novel therapeutic weapon against medullary thyroid cancer? Anticancer Res 36: 5019-5024, 2016

31 Marks PA: Discovery and development of SAHA as an anticancer agent. Oncogene 26: 1351-1356, 2007.

32 Marks P, Rifkind RA, Richon VM, Breslow R, Miller T and Kelly WK: Histone deacetylases and cancer: causes and therapies. Nat Rev Cancer 1: 194-202, 2001.

33 Slingerland M, Guchelaar HJ and Gelderblom H: Histone deacetylase inhibitors: an overview of the clinical studies in solid tumors. Anticancer Drugs 25: 140-149, 2014.

$34 \mathrm{Wu} \mathrm{S}$, Luo Z, Yu PJ, Xie H and He YW: Suberoylanilide hydroxamic acid (SAHA) promotes the epithelial mesenchymal transition of triple negative breast cancer cells via HDAC8/FOXA1 signals. Biol Chem 397: 75-83, 2016.

35 Zavadil $\mathrm{J}$ and Bottinger EP: TGF-beta and epithelial-tomesenchymal transitions. Oncogene 24: 5764-5774, 2005.

36 Zeisberg $M$ and Neilson EG: Biomarkers for epithelialmesenchymal transitions. J Clin Invest 119: 1429-1437, 2009.

37 Wolf I, Bose S, Williamson EA, Miller CW, Karlan BY and Koeffler HP: FOXA1: Growth inhibitor and a favorable prognostic factor in human breast cancer. Int J Cancer 120: 10131022, 2007.

38 Robinson JL and Carroll JS: FoxA1 is a key mediator of hormonal response in breast and prostate cancer. Front Endocrinol (Lausanne) 3: 68, 2012.

39 Kim YJ, Greer CB, Cecchini KR, Harris LN, Tuck DP and Kim TH: HDAC inhibitors induce transcriptional repression of high copy number genes in breast cancer through elongation blockade. Oncogene 32: 2828-2835, 2013.

40 Yan W, Liu S, Xu E, Zhang J, Zhang Y, Chen X and Chen X: Histone deacetylase inhibitors suppress mutant p53 transcription via histone deacetylase 8. Oncogene 32: 599-609, 2013.

41 Somoza JR, Skene RJ, Katz BA, Mol C, Ho JD, Jennings AJ, Luong C, Arvai A, Buggy JJ, Chi E, Tang J, Sang BC, Verner E, Wynands R, Leahy EM, Dougan DR, Snell G, Navre M, Knuth MW, Swanson RV, McRee DE and Tari LW: Structural snapshots of human HDAC8 provide insights into the class I histone deacetylases. Structure 12: 1325-1334, 2004.

$42 \mathrm{Hu}$ E, Chen Z, Fredrickson T, Zhu Y, Kirkpatrick R, Zhang GF, Johanson K, Sung CM, Liu R and Winkler J: Cloning and characterization of a novel human class I histone deacetylase that functions as a transcription repressor. J Biol Chem 275: 1525415264, 2000.

43 Oehme I, Deubzer HE, Wegener D, Pickert D, Linke JP, Hero B, Kopp-Schneider A, Westermann F, Ulrich SM, von Deimling A, Fischer $\mathrm{M}$ and Witt $\mathrm{O}$ : Histone deacetylase 8 in neuroblastoma tumorigenesis. Clin Cancer Res 15: 91-99, 2009.
44 Gunderson CC and Moore KN: Olaparib: an oral PARP-1 and PARP-2 inhibitor with promising activity in ovarian cancer. Future Oncol 11: 747-757, 2015.

45 Arun B, Akar U, Gutierrez-Barrera AM, Hortobagyi GN and Ozpolat B: The PARP inhibitor AZD2281 (Olaparib) induces autophagy/mitophagy in BRCA1 and BRCA2 mutant breast cancer cells. Int J Oncol 47: 262-268, 2015.

46 Min A, Im SA, Kim DK, Song SH, Kim HJ, Lee KH, Kim TY, Han SW, Oh DY, Kim TY, O'Connor MJ and Bang YJ: Histone deacetylase inhibitor, suberoylanilide hydroxamic acid (SAHA), enhances anti-tumor effects of the poly (ADP-ribose) polymerase (PARP) inhibitor olaparib in triple-negative breast cancer cells. Breast Cancer Res 17: 33, 2015.

47 Chiu HW, Yeh YL, Wang YC, Huang WJ, Chen YA, Chiou YS, Ho SY, Lin P and Wang YJ: Suberoylanilide hydroxamic acid, an inhibitor of histone deacetylase, enhances radiosensitivity and suppresses lung metastasis in breast cancer in vitro and in vivo. PLoS One 8: e76340, 2013.

48 Wang J, Xu H, Wang Q, Zhang H, Lin Y, Zhang H, Li Q and Panq T: CIAPIN1 targets $\mathrm{Na}(+) / \mathrm{H}(+)$ exchanger 1 to mediate MDA-MB-231 cells' metastasis through regulation of MMPs via ERK1/2 signaling pathway. Exp Cell Res 333: 60-72, 2015.

49 Cupić DF, Tesar EC, Ilijas KM, Nemrava J and Kovacević M: Expression of matrix metalloproteinase 9 in primary and recurrent breast carcinomas. Coll Antropol 35(Suppl 2): 7-10, 2011.

$50 \mathrm{Li} \mathrm{Y}$, Wu T, Zhang $\mathrm{B}$, Yao $\mathrm{Y}$ and Yin G: Matrix metalloproteinase-9 is a prognostic marker for patients with cervical cancer. Med Oncol 29: 3394-3399, 2012.

$51 \mathrm{Hu} \mathrm{X,} \mathrm{Li} \mathrm{D,} \mathrm{Zhang} \mathrm{W,} \mathrm{Zhou} \mathrm{J,} \mathrm{Tang} \mathrm{B} \mathrm{and} \mathrm{Li} \mathrm{L:} \mathrm{Matrix}$ metalloproteinase-9 expression correlates with prognosis and involved in ovarian cancer cell invasion. Arch Gynecol Obstet 286: 1537-1543, 2012.

52 Tang FY, Chiang EP and Sun YC: Resveratrol inhibits heregulinbeta1-mediated matrix metalloproteinase- 9 expression and cell invasion in human breast cancer cells. J Nutr Biochem 19: 287294, 2008.

53 Tang D, Piao Y, Zhao S, Mu X, Li S, Ma W, Song Y, Wang J, Zhao $\mathrm{W}$ and Zhang Q: Expression and correlation of matrix metalloproteinase-9 and heparanase in patients with breast cancer. Med Oncol 31: 26, 2014.

54 Palmieri D, Lockman PR, Thomas FC, Hua E, Herring J, Hargrave E, Johnson M, Flores N, Qian Y, Vega-Valle E, Taskar KS, Rudraraju V, Mittapalli RK, Gaasch JA, Bohn KA, Thorsheim HR, Liewehr DJ, Davis S, Reilly JF, Walker R, Bronder JL, Feigenbaum L, Steinberg SM, Camphausen K, Meltzer PS, Richon VM, Smith QR and Steeg PS: Vorinostat inhibits brain metastatic colonization in a model of triplenegative breast cancer and induces DNA double-strand breaks. Clin Cancer Res 15: 6148-6157, 2009.

55 Carlisi D, Lauricella M, D'Anneo A, Buttitta G, Emanuele S, di Fiore R, Martinez R, Rolfo C, Vento R and Tesoriere G: The synergistic effect of SAHA and parthenolide in MDAMB231 breast cancer cells. J Cell Physiol 230: 1276-1289, 2015.

56 D'Anneo A, Carlisi D, Lauricella M, Emanuele S, Di Fiore R, Vento $\mathrm{R}$ and Tesoriere G: Parthenolide induces caspaseindependent and AIF-mediated cell death in human osteosarcoma and melanoma cells. J Cell Physiol 228: 952-967, 2013. 
57 Sun Y, St Clair DK, Xu Y, Crooks PA and St Clair WH: A NADPH oxidase-dependent redox signaling pathway mediates the selective radiosensitization effect of parthenolide in prostate cancer cells. Cancer Res 70: 2880-2890, 2010.

58 Liu JW, Cai MX, Xin Y, Wu QS, Ma J, Yang P, Xie HY and Huang DS: Parthenolide induces proliferation inhibition and apoptosis of pancreatic cancer cells in vitro. J Exp Clin Cancer Res 29: 108, 2010.

59 Zhang S, Ong CN and Shen HM: Critical roles of intracellular thiols and calcium in parthenolide-induced apoptosis in human colorectal cancer cells. Cancer Lett 208: 143-153, 2004.

60 D'Anneo A, Carlisi D, Lauricella M, Puleio R, Martinez R, Di Bella S, Di Marco P, Emanuele S, Di Fiore R, Guercio A, Vento $\mathrm{R}$ and Tesoriere G: Parthenolide generates reactive oxygen species and autophagy in MDA-MB231 cells. A soluble parthenolide analogue inhibits tumour growth and metastasis in a xenograft model of breast cancer. Cell Death Dis 4: e891, 2013.

61 Carlisi D, D'Anneo A, Martinez R, Emanuele S, Buttitta G, Di Fiore R, Vento R, Tesoriere $\mathrm{G}$ and Lauricella M: The oxygen radicals involved in the toxicity induced by parthenolide in MDA-MB-231 cells. Oncol Rep 32: 167-172, 2014.

62 Lauricella M, Ciraolo A, Carlisi D, Vento R and Tesoriere G: SAHA/TRAIL combination induces detachment and anoikis of MDA-MB231 and MCF-7 breast cancer cells. Biochimie 94: 287-299, 2012.

63 Mitsiades CS, Mitsiades NS, McMullan CJ, Poulaki V, Shringarpure R, Hideshima T, Akiyama M, Chauhan D, Munshi N, Gu X, Bailey C, Joseph M, Libermann TA, Richon VM, Marks PA and Anderson KC: Transcriptional signature of histone deacetylase inhibition in multiple myeloma: biological and clinical implications. Proc Natl Acad Sci USA 101: 540-545, 2004.

64 Chen S, Zhao Y, Gou WF, Zhao S, Takano Y and Zheng HC: The anti-tumor effects and molecular mechanisms of suberoylanilide hydroxamic acid (SAHA) on the aggressive phenotypes of ovarian carcinoma cells. PLoS One 8: e79781, 2013.

65 Bali P, Pranpat M, Swaby R, Fiskus W, Yamaguchi H, Balasis M, Rocha K, Wang HG, Richon V and Bhalla K: Activity of suberoylanilide hydroxamic Acid against human breast cancer cells with amplification of her-2. Clin Cancer Res 11: 6382-6389, 2005.

66 Gammoh N, Lam D, Puente C, Ganley I, Marks PA and Jiang X: Role of autophagy in histone deacetylase inhibitor-induced apoptotic and nonapoptotic cell death. Proc Natl Acad Sci USA 109: 6561-6565, 2012.

67 Gordy C and He YW: The crosstalk between autophagy and apoptosis: where does this lead? Protein Cell 3: 17-27, 2012.

68 Wirawan E, Vande Walle L, Kersse K, Cornelis S, Claerhout S, Vanoverberghe I, Roelandt R, De Rycke R, Verspurten J, Declercq W, Agostinis P, Vanden Berghe T, Lippens S and Vandenabeele P: Caspase-mediated cleavage of Beclin-1 inactivates Beclin-1-induced autophagy and enhances apoptosis by promoting the release of proapoptotic factors from mitochondria. Cell Death Dis 1: e18, 2010.

69 Librizzi M, Spencer J and Luparello C: Biological effect of a hybrid anticancer agent based on kinase and histone deacetylase inhibitors on triple-negative (MDA-MB231) breast cancer cells. Int J Mol Sci 17: 1235, 2016

70 Zhang G, Park MA, Mitchell C, Hamed H, Rahmani M, Martin AP, Curiel DT, Yacoub A, Graf M, Lee R, Roberts JD, Fisher PB,
Grant S and Dent P: Vorinostat and sorafenib synergistically kill tumor cells via FLIP suppression and CD95 activation. Clin Cancer Res 14: 5385-5399, 2008.

71 Wawruszak A, Luszczki JJ, Grabarska A, Gumbarewicz E, Dmoszynska-Graniczka M, Polberg $\mathrm{K}$ et al: Assessment of interactions between cisplatin and two histone deacetylase inhibitors in MCF7, T47D and MDA-MB-231 human breast cancer cell lines - An Isobolographic Analysis. PLoS One 10: e0143013, 2015.

72 Dasari S and Tchounwou PB: Cisplatin in cancer therapy: molecular mechanisms of action. Eur J Pharmacol 740: 364-378, 2014.

73 Lin CT, Lai HC, Lee HY, Lin WH, Chang CC, Chu TY, Lin YW, Lee KD and Yu MH: Valproic acid resensitizes cisplatin-resistant ovarian cancer cells. Cancer Sci 99: 1218-1226, 2008.

74 Suzuki M, Endo M, Shinohara F, Echigo S and Rikiishi H: Enhancement of cisplatin cytotoxicity by SAHA involves endoplasmic reticulum stress-mediated apoptosis in oral squamous cell carcinoma cells. Cancer Chemother Pharmacol 64: 1115-1122, 2009.

75 Kim MS, Blake M, Baek JH, Kohlhagen G, Pommier Y and Carrier F: Inhibition of histone deacetylase increases cytotoxicity to anticancer drugs targeting DNA. Cancer Res 63: 7291-7300, 2003.

76 Kramer OH, Mahboobi S and Sellmer A: Drugging the HDAC6HSP90 interplay in malignant cells. Trends Pharmacol Sci 35: 501-519, 2014.

77 Cázares Marinero Jde J, Lapierre M, Cavaillès V, Saint-Fort R, Vessières $\mathrm{A}$, Top $\mathrm{S}$ and Jaouen G: Efficient new constructs against triple negative breast cancer cells: synthesis and preliminary biological study of ferrocifen-SAHA hybrids and related species. Dalton Trans 42: 15489-15501, 2013.

78 Hagen H, Marzenell P, Jentzsch E, Wenz F, Veldwijk MR and Mokhir A: Aminoferrocene-based prodrugs activated by reactive oxygen species. J Med Chem 55: 924-934, 2012.

79 Hillard E, Vessières A, Thouin L, Jaouen G and Amatore C: Ferrocene-mediated proton-coupled electron transfer in a series of ferrocifen-type breast-cancer drug candidates. Angew Chem Int Ed Engl 45: 285-290, 2005.

80 Hillard EA, de Abreu FC, Ferreira DC, Jaouen G, Goulart MO and Amatore $\mathrm{C}$ : Electrochemical parameters and techniques in drug development, with an emphasis on quinones and related compounds. Chem Commun (Camb) 23: 2612-2628, 2008.

81 Xiong F, Mou YZ and Xiang XY: Inhibition of mouse B16 melanoma by sodium butyrate correlated to tumor associated macrophages differentiation suppression. Int J Clin Exp Med 8: 4170-4174, 2015.

82 Demary K, Wong L and Spanjaard RA: Effects of retinoic acid and sodium butyrate on gene expression, histone acetylation and inhibition of proliferation of melanoma cells. Cancer Lett 163: 103-107, 2001.

83 Jazirehi AR: Regulation of apoptosis-associated genes by histone deacetylase inhibitors: implications in cancer therapy. Anticancer Drugs 21: 805-813, 2010.

84 Wang ZT, Chen ZJ, Jiang GM, Wu YM, Liu T, Yi YM, Zeng J, $\mathrm{Du} \mathrm{J}$ and Wang HS: Histone deacetylase inhibitors suppress mutant p53 transcription via HDAC8/YY1 signals in triple negative breast cancer cells. Cell Signal 28: 506-515, 2016.

85 Freed-Pastor WA and Prives C: Mutant p53: one name, many proteins. Genes Dev 26: 1268-1286, 2012. 
86 Shah SP, Roth A, Goya R, Oloumi A, Ha G, Zhao Y, Turashvili G, Ding J, Tse K, Haffari G, Bashashati A, Prentice LM, Khattra J, Burleigh A, Yap D, Bernard V, McPherson A, Shumansky K, Crisan A, Giuliany R, Heravi-Moussavi A, Rosner J, Lai D, Birol I, Varhol R, Tam A, Dhalla N, Zeng T, Ma K, Chan SK, Griffith M, Moradian A, Cheng SW, Morin GB, Watson P, Gelmon K, Chia S, Chin SF, Curtis C, Rueda OM, Pharoah PD, Damaraju S, Mackey J, Hoon K, Harkins T, Tadigotla V, Sigaroudinia M, Gascard P, Tlsty T, Costello JF, Meyer IM, Eaves CJ, Wasserman WW, Jones S, Huntsman D, Hirst M, Caldas C, Marra MA and Aparicio S: The clonal and mutational evolution spectrum of primary triple-negative breast cancers. Nature 486: 395-399, 2012.

87 Li D, Marchenko ND and Moll UM: SAHA shows preferential cytotoxicity in mutant p53 cancer cells by destabilizing mutant p53 through inhibition of the HDAC6-Hsp90 chaperone axis. Cell Death Differ 18: 1904-1913, 2011.

88 Wan M, Huang W, Kute TE, Miller LD, Zhang Q, Hatcher H, Wang J, Stovall DB, Russell GB, Cao PD, Deng Z, Wang W, Zhang Q, Lei M, Torti SV, Akman SA and Sui G: Yin Yang 1 plays an essential role in breast cancer and negatively regulates p27. Am J Pathol 180: 2120-2133, 2012.

89 Yoshida M, Horinouchi S and Beppu T: Trichostatin A and trapoxin: novel chemical probes for the role of histone acetylation in chromatin structure and function. Bioessays 17: 423-430, 1995.

90 Rodrigues MF, Carvalho É, Pezzuto P, Rumjanek FD and Amoêdo ND: Reciprocal modulation of histone deacetylase inhibitors sodium butyrate and trichostatin A on the energy metabolism of breast cancer cells. J Cell Biochem 116: 797-808, 2015.

91 Nural-Guvener HF, Zakharova L, Nimlos J, Popovic S, Mastroeni D and Gaballa MA: HDAC class I inhibitor, Mocetinostat, reverses cardiac fibrosis in heart failure and diminishes CD90+ cardiac myofibroblast activation. Fibrogenesis Tissue Repair 7: 10, 2014.

92 Zhang Q, Sun M, Zhou S and Guo B: Class I HDAC inhibitor mocetinostat induces apoptosis by activation of miR-31 expression and suppression of E2F6. Cell Death Discov 2: 16036, 2016.

93 Fournel M, Bonfils C, Hou Y, Yan PT, Trachy-Bourget MC, Kalita A, Liu J, Lu AH, Zhou NZ, Robert MF, Gillespie J, Wang JJ, Ste-Croix H, Rahil J, Lefebvre S, Moradei O, Delorme D, Macleod AR, Besterman JM and Li Z: MGCD0103, a novel isotype-selective histone deacetylase inhibitor, has broad spectrum antitumor activity in vitro and in vivo. Mol Cancer Ther 7: 759-768, 2008.

94 Bonfils C, Kalita A, Dubay M, Siu LL, Carducci MA, Reid G, Martell RE, Besterman $\mathrm{JM}$ and $\mathrm{Li} \mathrm{Z}$ : Evaluation of the pharmacodynamic effects of MGCD0103 from preclinical models to human using a novel HDAC enzyme assay. Clin Cancer Res 14: 3441-3449, 2008.

95 Sikandar S, Dizon D, Shen X, Li Z, Besterman J and Lipkin SM: The class I HDAC inhibitor MGCD0103 induces cell cycle arrest and apoptosis in colon cancer initiating cells by upregulating Dickkopf-1 and non-canonical Wnt signaling. Oncotarget 1: 596$605,2010$.

96 El-Khoury V, Moussay E, Janji B, Palissot V, Aouali N, Brons NH, Van Moer K, Pierson S, Van Dyck E and Berchem G: The histone deacetylase inhibitor MGCD0103 induces apoptosis in B-cell chronic lymphocytic leukemia cells through a mitochondria-mediated caspase activation cascade. Mol Cancer Ther 9: 1349-1360, 2010.
97 Borbely G, Haldosen LA, Dahlman-Wright K and Zhao C: Induction of USP17 by combining BET and HDAC inhibitors in breast cancer cells. Oncotarget 6: 33623-33635, 2015.

98 Fiskus W, Sharma S, Qi J, Valenta JA, Schaub LJ, Shah B, Peth K, Portier BP, Rodriguez M, Devaraj SG, Zhan M, Sheng J, Iyer SP, Bradner JE and Bhalla KN: Highly active combination of BRD4 antagonist and histone deacetylase inhibitor against human acute myelogenous leukemia cells. Mol Cancer Ther 13: 11421154, 2014.

99 Henssen A, Thor T, Odersky A, Heukamp L, El-Hindy N, Beckers A, Speleman F, Althoff K, Schäfers S, Schramm A, Sure U, Fleischhack G, Eggert A and Schulte JH: BET bromodomain protein inhibition is a therapeutic option for medulloblastoma. Oncotarget 4: 2080-2095, 2013.

100 Molenaar JJ, Domingo-Fernández R, Ebus ME, Lindner S, Koster J, Drabek K, Mestdagh P, van Sluis P, Valentijn LJ, van Nes J, Broekmans M, Haneveld F, Volckmann R, Bray I, Heukamp L, Sprüssel A, Thor T, Kieckbusch K, Klein-Hitpass L, Fischer M, Vandesompele J, Schramm A, van Noesel MM, Varesio L, Speleman F, Eggert A, Stallings RL, Caron HN, Versteeg R and Schulte JH: LIN28B induces neuroblastoma and enhances MYCN levels via let-7 suppression. Nat Genet 44: 1199-1206, 2012.

101 Burrows JF, Kelvin AA, McFarlane C, Burden RE, McGrattan MJ, De la Vega M, Govender U, Quinn DJ, Dib K, Gadina M, Scott CJ and Johnston JA: USP17 regulates Ras activation and cell proliferation by blocking RCE1 activity. J Biol Chem 284: 9587-9595, 2009.

102 Giltnane JM and Balko JM: Rationale for targeting the Ras/MAPK pathway in triple-negative breast cancer. Discov Med 17: 275-283, 2014.

103 Atadja P: Development of the pan-DAC inhibitor panobinostat (LBH589): successes and challenges. Cancer Lett 280: 233-241, 2009.

104 Ganai SA: Panobinostat: The small molecule metalloenzyme inhibitor with marvelous anticancer activity. Curr Top Med Chem 16: 427-434, 2016.

$105 \mathrm{Mu}$ S, Kuroda Y, Shibayama H, Hino M, Tajima T, Corrado C, Lin R, Waldron E, Binlich F and Suzuki K: Panobinostat PK/PD profile in combination with bortezomib and dexamethasone in patients with relapsed and relapsed/refractory multiple myeloma. Eur J Clin Pharmacol 72: 153-161, 2016.

106 Tate CR, Rhodes LV, Segar HC, Driver JL, Pounder FN, Burow $\mathrm{ME}$ and Collins-Burow BM: Targeting triple-negative breast cancer cells with the histone deacetylase inhibitor panobinostat. Breast Cancer Res 14: R79, 2012.

107 Kong D, Li Y, Wang Z and Sarkar FH: Cancer Stem Cells and Epithelial-to-Mesenchymal Transition (EMT)-Phenotypic Cells: Are They Cousins or Twins? Cancers (Basel) 3: 716729, 2011

108 Eger A, Aigner K, Sonderegger S, Dampier B, Oehler S, Schreiber M, Berx G, Cano A, Beug H and Foisner R: DeltaEF1 is a transcriptional repressor of E-cadherin and regulates epithelial plasticity in breast cancer cells. Oncogene 24: 23752385, 2005.

109 Comijn J, Berx G, Vermassen P, Verschueren K, van Grunsven L, Bruyneel E, Mareel M, Huylebroeck D and van Roy F: The two-handed $\mathrm{E}$ box binding zinc finger protein SIP1 downregulates E-cadherin and induces invasion. Mol Cell 7: 1267-1278, 2001. 
110 Rhodes LV, Tate CR, Segar HC, Burks HE, Phamduy TB, Hoang V, Elliott S, Gilliam D, Pounder FN, Anbalagan M, Chrisey DB, Rowan BG, Burow ME and Collins-Burow BM: Suppression of triple-negative breast cancer metastasis by pan-DAC inhibitor panobinostat via inhibition of ZEB family of EMT master regulators. Breast Cancer Res Treat 145: 593-604, 2014.

111 Zhou Q, Atadja P and Davidson NE: Histone deacetylase inhibitor LBH589 reactivates silenced estrogen receptor alpha (ER) gene expression without loss of DNA hypermethylation. Cancer Biol Ther 6: 64-69, 2007.

112 Aghdassi A, Sendler M, Guenther A, Mayerle J, Behn CO, Heidecke CD, Friess H, Büchler M, Evert M, Lerch MM and Weiss FU: Recruitment of histone deacetylases HDAC1 and HDAC2 by the transcriptional repressor ZEB1 downregulates Ecadherin expression in pancreatic cancer. Gut 61: 439-448, 2012.

113 Kakihana M, Ohira T, Chan D, Webster RB, Kato H, Drabkin $\mathrm{HA}$ and Gemmill RM: Induction of E-cadherin in lung cancer and interaction with growth suppression by histone deacetylase inhibition. J Thorac Oncol 4: 1455-1465, 2009.

114 Fortunati N, Marano F, Bandino A, Frairia R, Catalano MG and Boccuzzi G: The pan-histone deacetylase inhibitor LBH589 (panobinostat) alters the invasive breast cancer cell phenotype. Int J Oncol 44: 700-708, 2014.

115 Kai M, Kanaya N, Wu SV, Mendez C, Nguyen D, Luu T and Chen S: Targeting breast cancer stem cells in triple-negative breast cancer using a combination of LBH589 and salinomycin. Breast Cancer Res Treat 151: 281-294, 2015.

116 Miyazaki Y, Shibuya M, Sugawara H, Kawaguchi O and Hirsoe C: Salinomycin, a new polyether antibiotic. J Antibiot (Tokyo) 27: 814-821, 1974

117 Gupta PB, Onder TT, Jiang G, Tao K, Kuperwasser C, Weinberg RA and Lander ES: Identification of selective inhibitors of cancer stem cells by high-throughput screening. Cell 138: 645-659, 2009.

118 King TD, Suto MJ and Li Y: The Wnt/beta-catenin signaling pathway: a potential therapeutic target in the treatment of triple negative breast cancer. J Cell Biochem 113: 13-18, 2012.

119 Booth L, Roberts JL, Conley A, Cruickshanks N, Ridder T, Grant S, Poklepovic A and Dent P: HDAC inhibitors enhance the lethality of low dose salinomycin in parental and stem-like GBM cells. Cancer Biol Ther 15: 305-316, 2014.

120 Salvador MA, Wicinski J, Cabaud O, Toiron Y, Finetti P, Josselin E, Lelièvre H, Kraus-Berthier L, Depil S, Bertucci F, Collette Y, Birnbaum D, Charafe-Jauffret E and Ginestier C: The histone deacetylase inhibitor abexinostat induces cancer stem cells differentiation in breast cancer with low Xist expression. Clin Cancer Res 19: 6520-6531, 2013.

121 Al-Hajj M, Wicha MS, Benito-Hernandez A, Morrison SJ and Clarke MF: Prospective identification of tumorigenic breast cancer cells. Proc Natl Acad Sci USA 100: 3983-3988, 2003.

122 Ginestier C, Hur MH, Charafe-Jauffret E, Monville F, Dutcher J, Brown M, Jacquemier J, Viens P, Kleer CG, Liu S, Schott A, Hayes D, Birnbaum D, Wicha MS and Dontu G: ALDH1 is a marker of normal and malignant human mammary stem cells and a predictor of poor clinical outcome. Cell Stem Cell 1: 555-567, 2007.

123 Rao R, Balusu R, Fiskus W, Mudunuru U, Venkannagari S, Chauhan L, Smith JE, Hembruff SL, Ha K, Atadja P and Bhalla $\mathrm{KN}$ : Combination of pan-histone deacetylase inhibitor and autophagy inhibitor exerts superior efficacy against triplenegative human breast cancer cells. Mol Cancer Ther 11: 973$983,2012$.
124 Vabulas RM, Raychaudhuri S, Hayer-Hartl M and Hartl FU: Protein folding in the cytoplasm and the heat shock response. Cold Spring Harb Perspect Biol 2: a004390, 2010.

125 Trepel J, Mollapour M, Giaccone G and Neckers L: Targeting the dynamic HSP90 complex in cancer. Nat Rev Cancer 10: 537549, 2010.

126 Akerfelt M, Morimoto RI and Sistonen L: Heat shock factors: integrators of cell stress, development and lifespan. Nat Rev Mol Cell Biol 11: 545-555, 2010.

127 Rao R, Nalluri S, Fiskus W, Savoie A, Buckley KM, Ha K, Balusu R, Joshi A, Coothankandaswamy V, Tao J, Sotomayor E, Atadja P and Bhalla KN: Role of CAAT/enhancer binding protein homologous protein in panobinostat-mediated potentiation of bortezomib-induced lethal endoplasmic reticulum stress in mantle cell lymphoma cells. Clin Cancer Res 16: 4742-4754, 2010.

128 Tabas I and Ron D: Integrating the mechanisms of apoptosis induced by endoplasmic reticulum stress. Nat Cell Biol 13: 184190, 2011.

129 Rao R, Nalluri S, Kolhe R, Yang Y, Fiskus W, Chen J, Ha K, Buckley KM, Balusu R, Coothankandaswamy V, Joshi A, Atadja $\mathrm{P}$ and Bhalla KN: Treatment with panobinostat induces glucoseregulated protein 78 acetylation and endoplasmic reticulum stress in breast cancer cells. Mol Cancer Ther 9: 942-952, 2010.

130 Ginestier C, Wicinski J, Cervera N, Monville F, Finetti P, Bertucci F, Wicha MS, Birnbaum D and Charafe-Jauffret E: Retinoid signaling regulates breast cancer stem cell differentiation. Cell Cycle 8: 3297-3302, 2009.

131 Bhat-Nakshatri P, Goswami CP, Badve S, Sledge GW Jr and Nakshatri H: Identification of FDA-approved drugs targeting breast cancer stem cells along with biomarkers of sensitivity. Sci Rep 3: 2530, 2013.

132 Connolly RM, Nguyen NK and Sukumar S: Molecular pathways: current role and future directions of the retinoic acid pathway in cancer prevention and treatment. Clin Cancer Res 19: 1651-1659, 2013.

133 Tang XH and Gudas LJ: Retinoids, retinoic acid receptors, and cancer. Annu Rev Pathol 6: 345-364, 2011.

134 Sirchia SM, Ferguson AT, Sironi E, Subramanyan S, Orlandi R, Sukumar S and Sacchi N: Evidence of epigenetic changes affecting the chromatin state of the retinoic acid receptor beta2 promoter in breast cancer cells. Oncogene 19: 1556-1563, 2000.

135 Nacht M, Ferguson AT, Zhang W, Petroziello JM, Cook BP, Gao YH, Maguire S, Riley D, Coppola G, Landes GM, Madden SL and Sukumar S: Combining serial analysis of gene expression and array technologies to identify genes differentially expressed in breast cancer. Cancer Res 59: 5464-5470, 1999.

136 Sirchia SM, Ren M, Pili R, Sironi E, Somenzi G, Ghidoni R, Toma S, Nicolò G and Sacchi N: Endogenous reactivation of the RARbeta2 tumor suppressor gene epigenetically silenced in breast cancer. Cancer Res 62: 2455-2461, 2002.

137 Pili R, Salumbides B, Zhao M, Altiok S, Qian D, Zwiebel J, Carducci MA and Rudek MA: Phase I study of the histone deacetylase inhibitor entinostat in combination with 13-cis retinoic acid in patients with solid tumours. Br J Cancer 106: 77$84,2012$.

138 Merino VF, Nguyen N, Jin K, Sadik H, Cho S, Korangath P, Han L, Foster YM, Zhou XC, Zhang Z, Connolly RM, Stearns V, Ali SZ, Adams C, Chen Q, Pan D, Huso DL, Ordentlich P, Brodie A and Sukumar S: Combined treatment with epigenetic, 
differentiating, and chemotherapeutic agents cooperatively targets tumor-initiating cells in triple-negative breast cancer. Cancer Res 76: 2013-2024, 2016.

139 McNamara S, Wang $\mathrm{H}$, Hanna $\mathrm{N}$ and Miller WH Jr: Topoisomerase Ilbeta negatively modulates retinoic acid receptor alpha function: a novel mechanism of retinoic acid resistance. Mol Cell Biol 28: 2066-2077, 2008.

140 van Horssen R, Hollestelle A, Rens JA, Eggermont AM, Schutte $M$ and Ten Hagen TL: E-cadherin promotor methylation and mutation are inversely related to motility capacity of breast cancer cells. Breast Cancer Res Treat 136: 365-377, 2012.

141 Guarino M: Epithelial-mesenchymal transition and tumour invasion. Int J Biochem Cell Biol 39: 2153-2160, 2007.

142 Guarino M, Rubino B and Ballabio G: The role of epithelialmesenchymal transition in cancer pathology. Pathology 39: 305318, 2007.

143 Shah P, Gau Y and Sabnis G: Histone deacetylase inhibitor entinostat reverses epithelial to mesenchymal transition of breast cancer cells by reversing the repression of E-cadherin. Breast Cancer Res Treat 143: 99-111, 2014.

144 Fearon ER: Connecting estrogen receptor function, transcriptional repression, and E-cadherin expression in breast cancer. Cancer Cell 3: 307-310, 2003.

145 Peinado H, Ballestar E, Esteller M and Cano A: Snail mediates E-cadherin repression by the recruitment of the Sin3A/histone deacetylase 1 (HDAC1)/HDAC2 complex. Mol Cell Biol 4: 306319, 2004.

146 Vesuna F, van Diest P, Chen JH and Raman V: Twist is a transcriptional repressor of E-cadherin gene expression in breast cancer. Biochem Biophys Res Commun 367: 235-241, 2008.

147 Baranwal S and Alahari SK: Molecular mechanisms controlling E-cadherin expression in breast cancer. Biochem Biophys Res Commun 384: 6-11, 2009.

148 Whipple RA, Balzer EM, Cho EH, Matrone MA, Yoon JR and Martin SS: Vimentin filaments support extension of tubulinbased microtentacles in detached breast tumor cells. Cancer Res 68: 5678-5688, 2008.

149 Mani SA, Guo W, Liao MJ, Eaton EN, Ayyanan A, Zhou AY, Brooks M, Reinhard F, Zhang CC, Shipitsin M, Campbell LL, Polyak K, Brisken C, Yang J and Weinberg RA: The epithelialmesenchymal transition generates cells with properties of stem cells. Cell 133: 704-715, 2008.

150 Schech A, Kazi A, Yu S, Shah P and Sabnis G: Histone deacetylase inhibitor Entinostat inhibits tumor-initiating cells in triple-negative breast cancer cells. Mol Cancer Ther 14: 1848-1857, 2015.

151 Huang WJ, Chen CC, Chao SW, Yu CC, Yang CY, Guh JH, Lin YC, Kuo CI, Yang P and Chang CI: Synthesis and evaluation of aliphatic-chain hydroxamates capped with osthole derivatives as histone deacetylase inhibitors. Eur J Med Chem 46: 4042-4049, 2011.

152 Huang WJ, Tang YA, Chen MY, Wang YJ, Hu FH, Wang TW, Chao SW, Chiu HW, Yeh YL, Chang HY, Juan HF, Lin P and Wang YC8: A histone deacetylase inhibitor YCW1 with antitumor and antimetastasis properties enhances cisplatin activity against non-small cell lung cancer in preclinical studies. Cancer Lett 346: 84-93, 2014.
153 Chiu HW, Yeh YL, Wang YC, Huang WJ, Ho SY, Lin P and Wang YJ: Combination of the novel histone deacetylase inhibitor YCW1 and radiation induces autophagic cell death through the downregulation of BNIP3 in triple-negative breast cancer cells in vitro and in an orthotopic mouse model. Mol Cancer 15: 46, 2016.

154 Prestegui-Martel B, Bermúdez-Lugo JA, Chávez-Blanco A, Dueñas-González A, García-Sánchez JR, Pérez-González OA, Padilla-Martínez II, Fragoso-Vázquez MJ, Mendieta-Wejebe JE, Correa-Basurto AM, Méndez-Luna D, Trujillo-Ferrara $\mathrm{J}$ and Correa-Basurto J: N-(2-hydroxyphenyl)-2-propylpentanamide, a valproic acid aryl derivative designed in silico with improved anti-proliferative activity in HeLa, rhabdomyosarcoma and breast cancer cells. J Enzyme Inhib Med Chem 31(Suppl 3): 140-149, 2016.

155. Luu TH, Morgan RJ, Leong L, Lim D, McNamara M, Portnow J, Frankel P, Smith DD, Doroshow JH, Wong C, Aparicio A, Gandara DR and Somlo G: A phase II trial of vorinostat (suberoylanilide hydroxamic acid) in metastatic breast cancer: a California Cancer Consortium study. Clin Cancer Res 14: 7138$7142,2008$.

156. de Cremoux P, Dalvai M, N'Doye O, Moutahir F, Rolland G, Chouchane-Mlik O, Assayag F, Lehmann-Che J, Kraus-Berthie L, Nicolas A, Lockhart BP, Marangoni E, de Thé H, Depil S, Bystricky K and Decaudin D: HDAC inhibition does not induce estrogen receptor in human triple-negative breast cancer cell lines and patient-derived xenografts. Breast Cancer Res Treat 149: 81$89,2015$.

157. Biçaku E, Marchion DC, Schmitt ML and Münster PN: Selective inhibition of histone deacetylase 2 silences progesterone receptor-mediated signaling. Cancer Res 68: 15131519, 2008.

158. Dagdemir A, Judes G, Lebert A, Echegut M, Karsli-Ceppioglu S, Rifaï K, Daures M, Ngollo M, Dubois L, Penault-Llorca F, Bignon YJ and Bernard-Gallon D: Epigenetic modifications with DZNep, $\mathrm{NaBu}$ and SAHA in luminal and mesenchymal-like breast cancer subtype cells. Cancer Genomics Proteomics 13: 291-303, 2016.

159. Rodríguez-Paredes $M$ and Esteller $M$ : Cancer epigenetics reaches mainstream oncology. Nat Med 17: 330-339, 2011.

160 Hodges-Gallagher L, Valentine CD, Bader SE and Kushner PJ: Inhibition of histone deacetylase enhances the anti-proliferative action of antiestrogens on breast cancer cells and blocks tamoxifen-induced proliferation of uterine cells. Breast Cancer Res Treat 105: 297-309, 2007.

161 Sabnis GJ, Goloubeva O, Chumsri S, Nguyen N, Sukumar S and Brodie AM: Functional activation of the estrogen receptor- $\alpha$ and aromatase by the HDAC inhibitor entinostat sensitizes ERnegative tumors to letrozole. Cancer Res 71: 1893-1903, 2011.

Received May 26, 2017

Revised July 17, 2017

Accepted July 19, 2017 